\title{
Canadian Universities: Who Benefits and Who Pays?*
}

\author{
RONALD MENG and JIM SENTANCE†
}

\begin{abstract}
The following article deals with university education in Canada and its redistributive effects. From an economic point of view, there are two fundamental questions: first, which students are the principal beneficiaries of a university education? Secondly, who in Canadian society primarily bears the cost of educating university students? As the following article shows, the answers to these questions are not encouraging, if we view universities as institutions that strive for greater economic equality in Canada. Children of high income families tend to be the ones that capture the bulk of the financial rewards of a university degree, while low income families often pay a disproportionately large share of educational expenditures.
\end{abstract}

\section{RÉSUMÉ}

L'article suivant traite de l'éducation universitaire au Canada et de ses effets redistributifs. D'une perspective économique, il y a deux questions fondamentales à considérer: premièrement, quels étudiants sont les bénéficiaires principaux d'une éducation universitaire? Deuxièment, qui dans la société canadienne a la responsabilité principale de payer l'éducation des étudiants à l'université? Les réponses à ces questions, comme elles se présentent dans cet article, ne sont pas encourageantes, pour ceux qui considèrent que les universités sont des institutions qui visent une plus grande égalité économique au Canada. Les enfants des familles avec un revenu élevé sont en général ceux qui accaparent la plupart des récompenses économiques d'un diplôme universitaire, pendant que les familles de faible revenu prennent souvent une part disproportionnée du fardeau des frais de l'enseignement.

\footnotetext{
* We would like to thank Charles Seeto for his valuable comments.

$\dagger$ Lecturers, Department of Economics, Carleton University.
} 


\section{INTRODUCTION}

Most of the recent studies in the economics of education have been concerned with the contribution of education to economic growth and with the private and social returns to investment in different levels of education. By and large, these studies conclude that university education is a 'good thing' and that it 'pays off' (Dodge and Stager, 1972). The redistributive implications of public subsidization of higher education have been largely ignored. Mehmet (1978), as well as Meng, Seeto and Sentance (1982) are a few exceptions to this tendency.

It will be argued that public expenditure on university education will cause income redistribution. This will occur owing to a divergence between demand for various types of higher education by different income groups and their respective contributions to the tax system which supports such education. This becomes particularly relevant when one considers the scale of public funding of university education in Canada.

The theoretical basis for our analysis is the human capital theory. Obtaining a university education is deemed to impart to an individual certain specialized knowledge and skills which yield additional income to that person over their entire working life. The income-differential between university and high school graduates over their respective working lives embodies the return on the investment made in higher education by university students and their parents. Direct consumer satisfaction does not appear in this framework as part of the returns to education, and will not be included in our calculations. Some of the difficulties of calculating these benefits, as well as some simple estimates for the province of Ontario can be found in Anam et al. (1979).

With the use of human capital theory we can make positive (what is) statements about attending university and the redistribution of income. These are essentially empirical findings, and will be found in the next two sections.

Once we have discovered the redistributive effect of university education normative (what should be) questions emerge. That is, are there any policy questions that arise out of our empirical findings? If so, what are the most appropriate options to rectify any imbalances we may discover? Indeed, does the government even want to rectify any possible imbalances? These normative questions will be examined in the last section of our paper.

\section{METHODOLOGY}

It may be true that many general benefits to society are derived from education but for our purposes the "externalities" will not be directly considered. It is sometimes argued that the public should subsidize university education because of positive external benefits, e.g., better citizenry, reduced crime rates, consumer satisfaction, etc. However, since such benefits cannot be quantified, they will be ignored in our empirical work, though not in our interpretation of it. (For simplicity we can assume these consumption and external benefits are experienced uniformly by all income classes.) 
In order to perform a benefit-cost study of this type, a project has to be evaluated on a with-or-without basis, i.e., benefits and costs have to be compared with alternative possibilities. Accordingly, this study will compare the current Canadian university system with a hypothetical alternative that has a neutral impact on income distribution between various socio-economic groups. The alternative system has a "standardized" benefit-cost ratio of exactly 1.0 for each income group so that for every group, derived benefits equal its derived costs. ${ }^{1}$ For comparison, if under the current system, any group has a standardized benefitcost ratio of more than 1.0 , that group is gaining at the expense of some other group. Conversely, a group with a ratio of less than 1.0 is worse off than under a neutral system.

Proceeding from this, if the low-income groups as a whole have a benefit-cost ratio smaller than 1.0 while the high income groups have a ratio higher than 1.0 , then the system is termed regressive.

The present study will concentrate on students graduating from undergraduate programs. Due to data limitations we have to confine our study to the graduating class of 1974-5. Unfortunately, the necessary material needed to do such an analysis as ours has not been published since this date.

The benefits and costs calculated below are all in 1970 dollars. This is because of the fact that it was in 1970 that the 1974 graduating class (and their parents) took the decision to go to university. It is assumed that undergraduates attend university for four years.

The conventional approach in doing such a study would be to assign the total benefits and costs of a university education to different parental income classes and not to individual students (see Table I). Although this is the approach that will be adopted in this study, a problem does emerge.

One of the main sources of data for our study is the Post-Secondary Student Survey of 1975 (henceforth referred to as PSSS). This data tape contains information relating some 60,000 students' fields of study to their socio-economic backgrounds. Ideally we would like to relate males' incomes to their parents' total incomes. Unfortunately this cannot be done because of certain problems that exist with the PSSS tape. The students were requested to give information on their fathers' and mothers' incomes separately. Because the respective incomes were reported by economic class simple addition of the two groups is not possible. Secondly, the response rate of the questioned students concerning their mothers' incomes was exceedingly poor, and therefore deemed inappropriate for our purposes.

We only examine the male graduating class since it is impossible to generate any future income series for female graduates. Since women are often out of the work force a great deal of their potential working lives inclusion of this population could bias our results.

The PSSS was used to classify the various students by field of study and their fathers' incomes class as seen in Table I. This information is needed in order to assign the life-time benefits derived from a university degree and to allocate the costs to the various income classes. 
TABLE 1

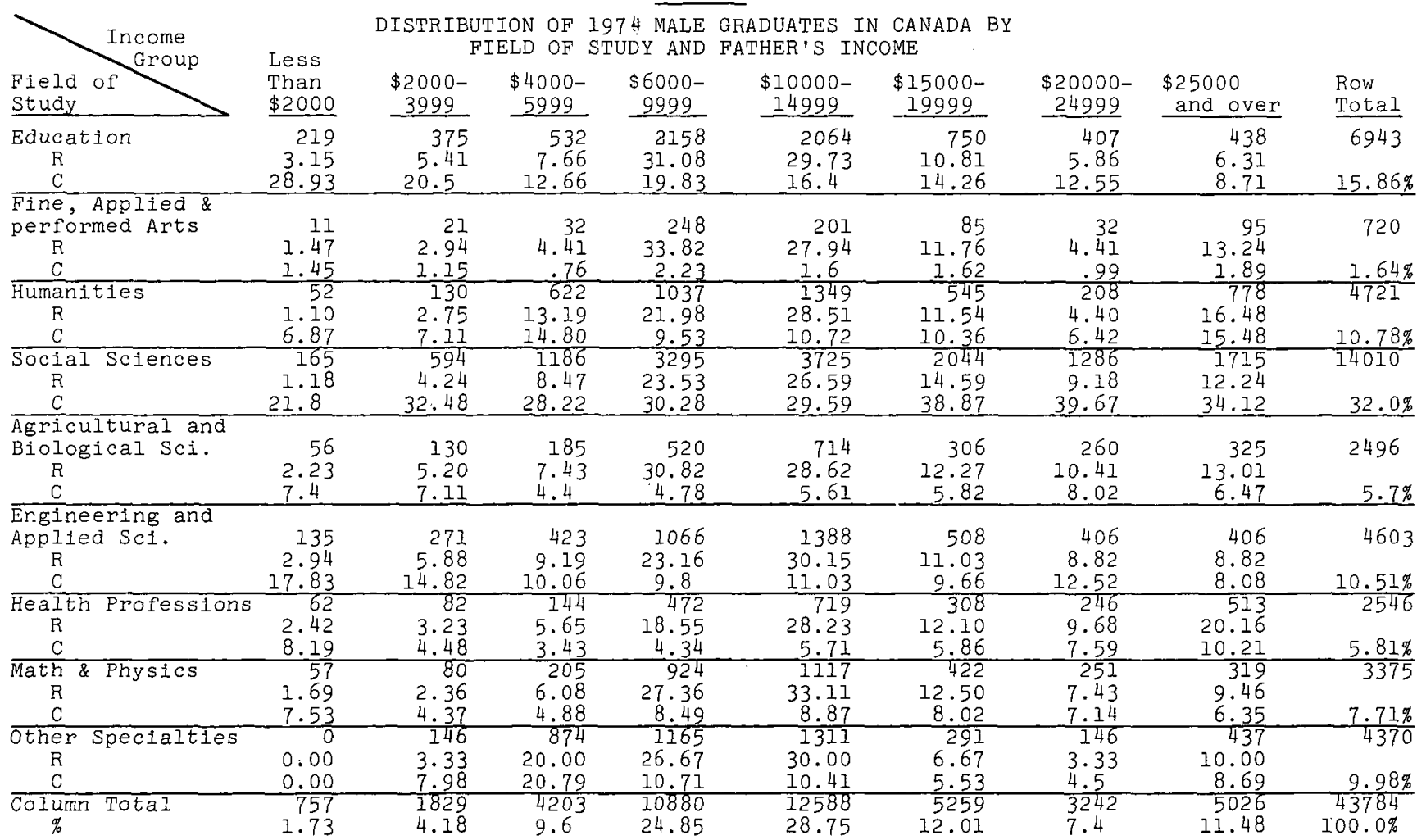

NOTE: $R$ is Row Percentage and $C$ is Column Percentage

SOURCE: Statistics Canada, Post-Secondary Student Survey (1975). Statist1cs Canada, Financial Statistics of Education $(1976)$. 
TABLE 2

PRESENT VALUE OF LIFETIME EARNINGS FOR CANADIAN UNIVERSITY MALE GRADUATES AND HIGH SCHOOL GRADS

Father's

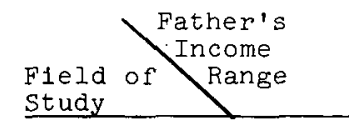

1. Education

2. Fine, Performed and Applied Arts

3. Humanities

4. Social Sciences

5. Agr. \& Bio. Sciences

6. Eng. \& Applied Sciences

7. Health Prof.

8. Math \& Physical Sciences

9. Gen. Arts \&

Sciences

10. Column Total

11. High School

12. Earnings at University

13. Net Benefits

14. Standardized Raio
Less

Than

$\$ 2000$

$\frac{\$ 2000}{24798}$

1168

5260

29834

$$
7864
$$

22711

16669

7582

0
115886
74936
3277
29632

\section{(Thousands)}

NOTE: In order to construct Table 2 the values from Table 5 (e.. , \$1l3,234 for education) were multiplied by the number of students in each cell (e.g., 219 for the Less than $\$ 2,000$ ) to derive the lifetime earnings (e.g., $\$ 24,798,000)$.

SOURCE: Tables 1 and 5 . 


\section{TABLE 3}

DISTRIBUTION OF COSTS BY INCOME GROUP

( 1970 \$ millions, discounted by $8 \%$ )

\begin{tabular}{|c|c|c|c|c|c|c|c|}
\hline & $\begin{array}{l}\text { Under } \\
\$ 2,000\end{array}$ & $\begin{array}{l}\$ 2,000- \\
\$ 3,999 \\
\end{array}$ & $\begin{array}{l}\$ 4,000- \\
\$ 5,999 \\
\end{array}$ & $\begin{array}{l}\$ 6,000- \\
\$ 9,999 \\
\end{array}$ & $\begin{array}{l}\$ 10,000- \\
\$ 14,999 \\
\end{array}$ & $\begin{array}{l}\$ 15,000 \\
\text { and over }\end{array}$ & Total \\
\hline Public Cost & $\begin{array}{l}10.8 \\
(1.92)\end{array}$ & $\begin{array}{l}30.3 \\
(5.40)\end{array}$ & $\begin{array}{l}52.6 \\
(9.37)\end{array}$ & $\begin{array}{l}164.1 \\
(29.22)\end{array}$ & $\begin{array}{l}156.2 \\
(27.82)\end{array}$ & $\begin{array}{l}147.5 \\
(26.27)\end{array}$ & $\begin{array}{l}561.5 \\
(100.0)\end{array}$ \\
\hline Private Cost & $\begin{array}{l}1.5 \\
(1.73)\end{array}$ & $\begin{array}{l}3.7 \\
(4.28)\end{array}$ & $\begin{array}{c}8.6 \\
(9.60)\end{array}$ & $\begin{array}{l}22.1 \\
(24.85)\end{array}$ & $\begin{array}{l}25.6 \\
(28.75)\end{array}$ & $\begin{array}{l}27.5 \\
(30.89)\end{array}$ & $\begin{array}{c}89.0 \\
(100.0)\end{array}$ \\
\hline
\end{tabular}

Less: Student Aid

Benefit

(i) Scholarships \& Grants

$$
\begin{array}{lcccccc}
1.4 & 2.5 & 4.9 & 10.5 & 11.2 & 8.1 & 38.6 \\
(3.74) & (6.59) & (12.66) & (27.06) & (29.05) & (20.90) & (100.0) \\
0.4 & 0.6 & 1.2 & 3.7 & 3.0 & 1.8 & 10.7 \\
(3.39) & (6.19) & (11.08) & (34.63) & (28.05) & (16.66) & (100.0) \\
10.5 & 30.9 & 55.1 & 172.0 & 167.6 & 165.1 & 601.2 \\
(1.75) & (5.14) & (9.16) & (28.61) & (27.88) & (27.46) & (100.0) \\
1.01 & 1.22 & .95 & 1.15 & .97 & .88 &
\end{array}
$$

TOTAL COST

$\begin{array}{lllllll}10.5 & 30.9 & 55.1 & 172.0 & 167.6 & 165.1 & 601.2 \\ (1.75) & (5.14) & (9.16) & (28.61) & (27.88) & (27.46) & (100.0)\end{array}$

Standardized Ratios

$\begin{array}{lllll}1.01 & 1.22 & .95 & 1.15 & .97\end{array}$

NOTE: The bracketed figures are percentages. If a standardized Ratio is less than 1.0 the income class is "underpaying", and if it is over 1.0 they are "overpaying". See Footnote 3.

SOURCE: Statistics Canada, Financial Statistics of Education (1976). W.I. Gillespie, Redistribution of Income in Canada (1980). 


\section{Benefits}

Once we know how many students are studying in the various fields it is possible to estimate what their future incomes (benefits) will be. By use of the Highly Qualified Manpower Survey developed by Statistics Canada we were able to project what these graduates will make over their working lives (ages 22 to 65). These estimates are shown in Table 2, lines 1 through 10 .

Since, as stated earlier, we are interested in the income differential between university and high school graduates the "opportunity cost" of going to university must be netted out, i.e., the money these students would have made if they did not go to university. These calculations came from the Survey of Consumer Finances and are reported in Table 2 (line 11). Finally, to these figures we add the income that the various students made while they were attending university (line 12). ${ }^{2}$

\section{Costs}

In Canada our university system is financed both out of public and private funds, although the former source is monetarily far more significant. In 1974 funds from federal and provincial governments accounted for 80 percent of the total expenditures on university education while fees paid by students accounted for only 12 percent. The remaining 8 percent came from other sources, mainly endowments (Statistics Canada, 1976).

In this study the public cost of university education for the 1974 male graduate is determined from the point of view of parents whose taxes are the major source of university funding. In paying taxes the parents are foregoing consumption (or potential consumption). The data used for these calculations, along with the student aid benefits come from Statistics Canada (1976) and Gillespie's (1980) tax estimates.

The private cost component consists of fees paid by students and other academic expenses. The principal sources of information for these costs come from the PSSS tape and the Department of the Secretary of State (1976).

The distribution of total cost by income group is provided in Table 3 . The first row shows the public cost of supporting universities in Canada. This includes both federal and provincial subsidies, as well as some local municipal imputed costs. The second row lists the private cost of going to school (tuition, books, etc.). From these figures we subtract scholarships and grants as well as student loans to arrive at a total cost figure.

Although presentation of the cost figures is straight-forward, estimating the costs of a university education is infinitely more difficult than estimating the benefits. ${ }^{3}$ This is because many of the costs are imputed (to various income groups and levels of government) and detailed tax data has to be analyzed (Gillespie, 1980; Statistics Canada, 1976).

\section{RESULTS}

The basic findings of our study are found in Table 4 , using an 8 percent discount rate. Column (1) shows the various income groups we are examining. ${ }^{4}$ Columns 
TABLE 4

AGGREGATED DISCOUNTED BENEFITS AND COSTS AT

CONSTANT COSTS AND BENEFIT-COST RATIOS

(1)

$$
\begin{aligned}
& \text { Income } \\
& \text { Groups } \\
& <\$ 2,000 \\
& \$ 2,000- \\
& \$ 3,999 \\
& \$ 4,000- \\
& \$ 5,999 \\
& \$ 6,000- \\
& \$ 9,999 \\
& \$ 10,000- \\
& \$ 14,999 \\
& \$ 15,000 \text { and } \\
& \text { over }
\end{aligned}
$$

Total
(2)

\begin{abstract}
Aggregated
Discounted

(@8\%) Benefits

(\$milions)
\end{abstract}

29.6

$73 \cdot 3$

152.9

408.3

496.9

597.7

1758.9
(3)

\begin{tabular}{l} 
Aggregated \\
Discounted \\
(@8\%) Costs \\
( $\$$ millions) \\
\hline
\end{tabular}

10.5

30.9

55.1

172.0

167.6

165.1

601.2
(4)

Benefit

Cost

Ratio

(Actual)

2.82

$2 \cdot 37$

2.77

2.37

2.96

3.62

1.24

2.92
(5)

Benefit

Cost

Ratio

(Standardized)

0.96

0.81

0.95

0.81

1.01

NOTE: Column (1) shows the income groups we are examining. (2) shows the lifetime benefits for going to university (Table 2). (3) incorporates all the costs of a university education (Table 3). (4) and (5) show the benefit cost ratios.

In order to derive (5) divide the standardized ratios in Table (2) with those in Table (3).

SOURCE: Tables 2 and 3.

(2) and (3) show the actual benefits and costs for each income class respectively. The columns of principal interest are of course Columns (4) and (5). From the former it can be seen that the aggregate benefit-cost ratio (the benefits divided by the costs) is 2.92 . This means that investment in a university education is worthwhile since the financial returns far exceed the costs.

As stated earlier we are ignoring any external benefits of education, as they cannot be quantified. If these benefits do exist the aggregate benefit-cost ratio would be much larger.

It would be inappropriate to stop at this point and simply state that a university degree is a 'good thing'. The question we are most interested in deals with identifying those income groups who receive most of the financial rewards of going to university and those who receive the least. Column (5) examines this very point. As can be seen from the table the highest income group (over $\$ 15,000$ ) receives the greatest share from the Canadian university system (a ratio of 1.24), while the lower income classes are relatively worse off. 


\section{TABLE 5}

DISCOUNTED PRESENT VALUES OF PERMANENT INCOME STREAM

\section{Classification}

1. Education

2. Fine Arts \& Music

3. Humanities

4. Social Sciences

5. Agricultural \& Biol.Sci.

6. Engineering and Applied Scie.

7. Health

8. Maths. \& Physical Sci.

9. General Arts and Science

10. High School
Amount (\$)

$\$ 113,234$

106,157

101,159

180,816

140,425

168,226

268,861

133,011

139,038

98,991

NOTE: Although these academic classifications are quite broadly aggregated it is impossible to break them down in any more detail. We are following standard Statistics Canada procedures for classifying students (See Statistics Canada, 1976, for a more detailed breakdown).

SOURCE: Survey of Consumer Finances (1970), Statistics Canada (1976) and Statistics Canada (1973).

It must be concluded that the flow of benefits and costs within the subset of the population that goes to university are decidedly regressive in nature. On a purely distributional basis, rather than being "pro-poor", universities are definitely "pro-rich".

\section{Implications}

We have found the provision of university education in Canada to be distributionally regressive. This is both because the university system is financed in a regressive fashion (Gillespie, 1980) and because the benefits that accrue to university educations do so regressively (Table 2 , line 14). If we accept the normative judgement that public provision of the university system should be distributionally neutral, then this finding is of concern. When considering policy options, governments may want to consider the broader question of distributive justice in the provision of all types of training - institutional and otherwise - but in the absence of information on these considerations we will ask here how we might arrive at a distributionally neutral university system. 
Obviously we can begin with either financing or the distribution of benefits. The regressivity of the former we see in Table 3 to be largely the result of depending for the bulk of university funding upon public funds that are collected in a regressive fashion. Two approaches to this difficulty come to mind: first, altering the tax system which provides these funds, so that they fall less heavily on lower-income groups; and second, shifting the burden of finance towards private sources. This second option - that of approaching a 'user-pay' principle - would most probably involve difficulties in access for lower-income groups. Given that our governments generally accept the principle of equality of access this would involve further policy initiatives such as extended student loan or voucher programs (which entail their own distributional questions).

The distribution of benefits we found (Table 2 ) derives its regressivity from the usage patterns that prevail in the different income groups. A neutral system would change these patterns. How this is to be done should, however, depend upon what the causal mechanism is behind present patterns, the most efficient solution being the one that addresses the root of the problem.

The result we observe comes, in the human capital theoretic framework we have adopted, from both supply and demand forces. The possibility exists, therefore, that either individuals choose the programs they do in response to "price tags' that differ according to their income backgrounds, or that their choice is influenced by what their background has prepared them for directly and leads them to expect they can gain from a given degree.

Student aid programs have been labelled as inadequate in that they do not make longer or more expensive educations affordable to lower-income students, and elitist entry procedures are asserted to have aggravated the problem (Mehmet, 1978). On the other hand socio-economic background has been found by numerous researchers (Buttrick, 1977; the Economic Council of Canada, 1971) to impact seriously on the demand side. Lower income students are channelled by the public school system into less ambitious programs; factors external to the school system do the same thing; and the prospect of unequal treatment in the labour market deters lower income students from obtaining financially rewarding degrees.

Both propositions have been inadequately argued and investigated and deserve further consideration and research. Neither has been established to the point where more than general policy prescriptions follow - more student aid, less elitist entry, encouragement in lower grades, an end to labour market discrimination. Moreover, whatever the facts are, pursuit of distributional equity along these lines involves answering additional normative questions often ignored. Changing accessibility, to judge from the work of West (1975) and West and McKee (1977), would not seem to be possible without subsidies of some form. This implies overall positive redistribution effects. On the other hand, a demand oriented approach to balancing benefits implies a degree of equality of outcome that our society may not agree with - certainly the Ontario Economic Council (1976) does not. 
Choosing from these options will involve not only the decision to approach distributional equity. Most involve if not equity of outcomes from university at least equality of access - and these are not bought by society for nothing. An essential ingredient in making these choices will be further research into the positive questions outlined above, in particular into the extent of the tradeoffs involved. Only when these costs are known can we expect society to decide what it wants to do about it.

\section{FOOTNOTES}

1. As seen in Table 4 the aggregate benefit-cost ratio for attending university is 2.92 . To be distributionally neutral each income class's actual ratio should be 2.92 . If their ratio is greater than this figure they are gainers, and if it is less they are losers. Our standardized ratios explicitly examine the distributional impact of a public financed university system. They say nothing about whether universities are good from a social standpoint.

2. The standardized ratios for Table 2 are calculated on a per capita basis. Take for example the less than $\$ 2,000$ income group. The number of students (757) divided by the total population (43784) found in Table 1 gives the fraction of students from that class who graduated from university. If the university system is distributionally neutral they should acquire the same fraction of benefits; so that the latter divided by the former yields a value of 1.0. In actual fact the benefits (29632 divided by 1758889$)$ divided by the fraction of students from the less than $\$ 2,000$ class yields a ratio of .97 . The same procedure is used in doing standard costs, except in reverse. The percentage of total costs ( 1.75 percent for the less than $\$ 2,000$ ) is divided by the percent of students in that class (1.73 percent) to yield a standardized cost figure (1.01).

3. This difficulty can best be appreciated if the reader examines our estimates and then Mehmet's (1978). We are at odds as to how to accurately calculate the burden of financing post-secondary education in Canada.

4. The PSSS tape has for its highest income class $\$ 25,000$ and over (see Table 1). Gillespie's (1980) tax estimates have $\$ 15,000$ and over as the highest income class. In order to make the benefit and cost side comparable we used as our highest income range $\$ 15,000$ and over, this merging the three highest income groups in the PSSS tape.

\section{REFERENCES}

Anam, M., Noordeh, A. \& Rahman, S. The distributional effects of public expenditure in post secondary education: A case study of Ontario, 1969. Carleton Economic Papers (79-11).

Buttrick, J. Educational problems in Ontario and some policy options. OEC Occasional Working paper \#4, Toronto: Ontario Government, 1977.

Department of Secretary of State. Some characteristics of post-secondary students in Canada, Ottawa, 1976.

Dodge, D. \& Stager, D. Economic returns to graduate study. Canadian Journal of Economics, 1972, 5(2), 182-198.

Economic Council of Canada. Design for decision making, Ottawa, 1971.

Gillespie, W.I. The redistribution of income in Canada, Ottawa: Carleton Library Series \#124, 1980. 
Mehmet, $\mathrm{O}$. Who benefits from the Ontario university system? OEC occasional working paper \#7, Toronto: Ontario Economic Council, 1978.

Mehmet, 0 . The Ontario university system as wealth creator: Who benefits? Who Pays?. Canadian Journal of Higher Education, 1979, 9(3), 41-55.

Meng, R., Seeto, C. \& Sentance, J. A reconsideration of Canadian universities and the redistribution of income, Ottawa: Carleton University, Centre for Policy and Program Assessment, 1982.

Ontario Economic Council. Issues and alternatives. Toron to: Committee on Education, 1976.

Statistics Canada, Survey of consumer finances (data tape). Ottawa, 1970.

Statistics Canada, Highly qualified manpower survey. Ot tawa, 1973.

Statistics Canada. Post-secondary student survey (data tape). Ottawa, 1975.

Statistics Canada, Financial statistics of education. Ottawa, cat. 81-208, 1976.

West, E. Student loans: A reappraisal. OEC working paper \#4, Toronto: Ontario Economic Council, 1975.

West, E. \& McKee, M. Imperfect capital markets as barriers to education. Atlantic Economic Journal, 5(2), 1977. 